\title{
Exploration of orbital and orbital soft-tissue volume changes with gender and body parameters using magnetic resonance imaging
}

\author{
MUSTAFA FATIH ERKOÇ ${ }^{1}$, BILGE ÖZTOPRAK ${ }^{2}$, CESUR GÜMÜŞ ${ }^{2}$ and AYLIN OKUR ${ }^{1}$ \\ ${ }^{1}$ Department of Radiology, Bozok Medical Faculty, Yozgat 66200; \\ ${ }^{2}$ Department of Radiology, Cumhuriyet Medical Faculty, Sivas 58100, Turkey
}

Received October 10, 2014; Accepted February 16, 2015

DOI: $10.3892 / \mathrm{etm} .2015 .2313$

\begin{abstract}
The aim of the present study was to examine the total orbital volume (TOV) and total orbital fat volume (TOFV) in normal orbits in different age groups and to investigate the correlation of these measurements with age, gender and body parameters by magnetic resonance imaging (MRI). MRI data were acquired retrospectively from a total of 1,453 subjects divided into five age groups with 10 -year intervals. The TOV and TOFV were measured using T1-weighted MRI for each subject and body parameters were also obtained. The measurements demonstrated that TOV increased with age and that the volume was larger in men than in women. While weight and height exhibited positive correlations with TOV in male and female subjects in the 20-29, 30-39 and 40-49-year-old age groups, only weight showed a positive correlation with TOV in female subjects in the 50-59 and 60-69-year-old age groups. However, TOFV increased by age in all groups and the increments were larger in women than in men. These results provide basic information about the effect of age, gender and body parameters on TOV and TOFV. The variations in TOV are associated with orbital soft-tissues changes rather than with TOFV.
\end{abstract}

\section{Introduction}

Since the volume of the orbit is a significant determinant of the facial appearance (1), and is influenced by many diseases and situations, understanding the volumetric values and changes with respect to body parameters and gender is likely to be of guidance in the resolution of serious clinical issues, such as when studying the mechanisms of exophthalmos in Graves' orbitopathy, planning orbital decompression, orbital reconstruction following fractures, determining the size of orbital

Correspondence to: Dr Mustafa Fatih Erkoç, Department of Radiology, Bozok Medical Faculty, 118 Adnan Menderes Boulevard, Yozgat 66200, Turkey

E-mail: drerkoc@gmail.com

Key words: orbit, gender, body weight, body height, magnetic resonance imaging implants following enucleation, or conducting esthetic procedures such as blepharoplasty. Previous studies have examined factors affecting the orbital or eyeball volume by computed tomography (CT) or magnetic resonance imaging (MRI) (2-4). Chau et al (4) reported that MRI provided more accurate results than CT in orbital and eyeball volume measurements. Ranly (5) observed that the orbital volume is proportional to eyeball volume since the orbit is associated with the growth of the bone and eyeball. Kahn et al (6) reported the change of orbital size with respect to age, but did not study orbital volumes. Previous studies have examined volumetric measurements of the orbit and their variability (7-9) with gender or body parameters; however, volumetric parameters were examined separately in these studies, and in a limited number of cases. The aim of the present study was to examine the total orbital volume (TOV) and total orbital fat volume (TOFV) together, and to investigate their correlation with clinical parameters, such as age, gender, height and weight, in a large group of patients in order to the determine the effect of these parameters on orbital appearance, as well as to identify racial differences in orbital volume.

\section{Materials and methods}

Subjects. Ethical approval for the present study was obtained from the Bozok Medical Faculty Ethics Committee (Yozgat, Turkey). Informed consent was obtained from each patient prior to their details being used in the current study. A retrospective review was undertaken in the radiology department. Subjects were selected from the patients who had been referred to the radiology departments of the Bozok and Cumhuriyet Universities (Yozgat and Sivas, Turkey, respectively) in the previous 3 years for orbital or maxillofacial evaluation. Thinslice cranial magnetic resonance (MR) images of patients obtained for various reasons, such as frontal mass or vascular lesions, which did not directly affect the orbital structures, were also selected for orbital measurements. Patients with a history of previous surgery, trauma or infection of ocular, orbital or periorbital structures, and who had any refractive errors, heterotropia, mass lesions involving the maxilla or adjacent structures, and osteomyelitis of the maxilla, and patients with known thyroid-associated orbitopathy or hyperthyroidism were excluded to rule out the potential effects of these factors on measurements. A total of 1,453 Anatolian 
Table I. Mean \pm standard deviation (SD) ages of the participants and the number of subjects in each group.

\begin{tabular}{|c|c|c|c|c|c|c|c|}
\hline \multirow[b]{2}{*}{ Groups } & \multirow[b]{2}{*}{$\begin{array}{c}\text { Age range, } \\
\text { years }\end{array}$} & \multicolumn{2}{|c|}{ Male } & \multicolumn{2}{|c|}{ Female } & \multicolumn{2}{|c|}{ Male + female } \\
\hline & & $\mathrm{n}$ & $\begin{array}{c}\text { Age, years } \\
(\text { mean } \pm \text { SD) }\end{array}$ & $\mathrm{n}$ & $\begin{array}{c}\text { Age, years } \\
(\text { mean } \pm \text { SD })\end{array}$ & $\mathrm{n}$ & $\begin{array}{c}\text { Age, years } \\
(\text { mean } \pm S D)\end{array}$ \\
\hline Group I & $20-29$ & 162 & $27.8 \pm 1.1$ & 175 & $24.8 \pm 3.3$ & 337 & $26.3 \pm 2.9$ \\
\hline Group II & $30-39$ & 151 & $36.5 \pm 3.3$ & 168 & $32.1 \pm 2.1$ & 319 & $34.3 \pm 3.0$ \\
\hline Group III & $40-49$ & 149 & $45.2 \pm 3.9$ & 166 & $43.8 \pm 5.1$ & 315 & $44,5 \pm 4.6$ \\
\hline Group IV & $50-59$ & 163 & $56.1 \pm 4.1$ & 148 & $56.9 \pm 3.9$ & 311 & $56.5 \pm 4.1$ \\
\hline Group V & $60-69$ & 80 & $66.9 \pm 4.1$ & 91 & $64.9 \pm 4.0$ & 171 & $65.9 \pm 4.0$ \\
\hline Total & $20-69$ & 705 & $46.5 \pm 13.8$ & 748 & $44.5 \pm 13.4$ & 1,453 & $45.5 \pm 13.5$ \\
\hline
\end{tabular}

subjects with ages ranging from 20 to 69 years (705 males and 748 females) were selected and grouped into five age groups with 10 -year intervals. Table I shows the range of ages and the mean \pm standard deviation (SD) age for each group of patients.

Image acquisition. All MRI examinations were performed using a whole body 1.5-T unit (Magnetom Symphony; Siemens, Germany) with a 16-channel sensitivity encoding (SENSE) head coil. T1-weighted (T1W) axial, coronal and sagittal images were analyzed. T1W-turbo spin echo (TSE) images were obtained with the following parameters: repetition time (TR)/echo time (TE)/number of signal averages (NSA), $114 \mathrm{msec} / 3,810 \mathrm{msec} / 1$; flip angle, $150^{\circ}$; matrix, 256x192; field of view (FOV), 17.8x17.4 cm; bandwidth, $130 \mathrm{kHz}$; echo train length, 13; and slice thickness, $3 \mathrm{~mm}$.

Volumetry. For the determination of TOV in axial slices, the posterior boundary of the orbit was defined as the crossing line of the medial and lateral walls of the optic foramen. The anterior boundary of the orbit was defined as the line that connects the two end points of the front medial and lateral walls and which lies down the cornea (Fig. 1). The eyelids were included, since they are challenging to separate from the anterior boundary of the cornea and sclera. Following assignment of the region of interest (ROI) by two radiologists in consensus, and the area of the ROI multiplied by slice thickness, TOV was calculated by summing these volumes in each slice in T1W axial images.

Since the orbital cavity volume inside the bony orbit includes the eyeball, orbital muscles, optic nerve and orbital fatty tissues, when determining the TOFV, the eyeball, optic nerve, lacrimal gland and orbital muscle volumes were subtracted from the TOV, with the exception of the vasculature which is almost impossible to outline volumetrically; the difference was recorded as the TOFV. In order to do this, the volumes of the medial rectus muscle (MRM), inferior rectus muscle (IRM), lateral rectus muscle (LRM), superior rectus-levator palpebrae superioris muscle complex (SRM-LPSM) and superior oblique muscle (SOM) were measured in T1W coronal images by summing the cross-sectional areas in every section and multiplying by the image plane thickness. Inferior oblique muscle (IOM) and optic nerve (ON) volumes were calculated

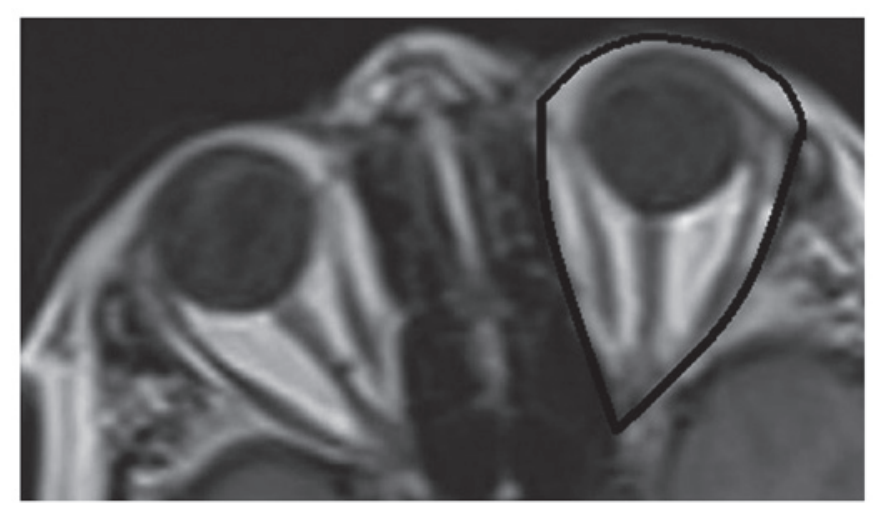

Figure 1. Region of interest (ROI) used for calculating the total orbital volume (TOV) in a T1-weighted axial image.

similarly on T1W sagittal images, as described by Detorakis et al $(10,11)$ (Fig. 2).

Statistical analysis. Clinical information (age, gender, height and weight) was obtained for each subject. Continuous variables were expressed as the mean $\pm \mathrm{SD}$. To investigate the effect of age and gender on the TOV and TOFV, two-way analysis of variance (ANOVA) was employed using SPSS software (version 15.0; SPSS, Inc., Chicago, IL, USA), in which age and gender (with two levels) were used as two independent variables. A multiple regression analysis was performed to determine the effect of the body parameters (height and weight) on the change in TOV and TOFV with respect to age and gender. P-values less than 0.05 were considered to be statistically significant.

\section{Results}

$T O V$. The mean TOV of all men was $32.21 \pm 1.55 \mathrm{~cm}^{3}$, and that of all women was $31.11 \pm 1.87 \mathrm{~cm}^{3}$ and the overall average for the study population was $31.66 \pm 1.91 \mathrm{~cm}^{3}$. The mean TOV of men was significantly greater than that of women $(\mathrm{P}<0.001)$, and the mean TOV of all subjects in group $\mathrm{V}$ was greater than that of all other groups $(\mathrm{P}<0.001)$, demonstrating that TOV increased with age (Table II). There was no significant difference between the right and left orbital volumes for either men or women. As shown in Table III and Fig. 3, there was 
Table II. Average TOV and TOFV (in $\mathrm{cm}^{3}$ ) with respect to gender and age.

\begin{tabular}{|c|c|c|c|c|c|c|}
\hline \multirow[b]{2}{*}{ Group } & \multicolumn{2}{|c|}{ Male } & \multicolumn{2}{|c|}{ Female } & \multicolumn{2}{|c|}{ Male + female } \\
\hline & TOV & TOFV & TOV & TOFV & TOV & TOFV \\
\hline Group I & $29.99 \pm 1.47$ & $9.83 \pm 1.32$ & $29.13 \pm 1.74$ & $10.34 \pm 1.73$ & $29.56 \pm 1.47$ & $10.08 \pm 1.64$ \\
\hline Group II & $31.33 \pm 1.88$ & $10.65 \pm 1.45$ & $29.17 \pm 1.65$ & $11.24 \pm 1.35$ & $30.25 \pm 1.28$ & $10.94 \pm 1.26$ \\
\hline Group III & $31.99 \pm 1.28$ & $11.46 \pm 1.74$ & $31.33 \pm 1.88$ & $12.22 \pm 1.40$ & $31.66 \pm 1.35$ & $11.84 \pm 1.59$ \\
\hline Group IV & $33.02 \pm 1.33$ & $12.54 \pm 1.82$ & $32.66 \pm 1.36$ & $13.18 \pm 1.82$ & $32.84 \pm 1.25$ & $12.86 \pm 1.41$ \\
\hline Group V & $34.75 \pm 1.38$ & $12.93 \pm 1.34$ & $33.29 \pm 1.82$ & $13.77 \pm 1.33$ & $34.02 \pm 1.88$ & $13.35 \pm 1.49$ \\
\hline Total & $32.21 \pm 1.55$ & $11.48 \pm 1.81$ & $31.11 \pm 1.87$ & $12.15 \pm 1.66$ & $31.66 \pm 1.91$ & $11.81 \pm 1.88$ \\
\hline
\end{tabular}

TOV, total orbital volume; TOFV, total orbital fat volume.

Table III. Results of TOV and TOFV analysis with ANOVA, using age and gender as independent variables.

\begin{tabular}{|c|c|c|c|c|c|c|c|c|c|}
\hline \multirow[b]{2}{*}{ Source } & \multicolumn{2}{|c|}{ Type III sum of squares } & \multirow[b]{2}{*}{ d.f } & \multicolumn{2}{|c|}{ Mean square } & \multicolumn{2}{|c|}{$\mathrm{F}$} & \multicolumn{2}{|c|}{ P-value } \\
\hline & TOV & TOFV & & TOV & TOFV & TOV & TOFV & TOV & TOFV \\
\hline Corrected model & 382.397 & 256.198 & 3 & 132.655 & 111.583 & 49.587 & 42.314 & 0.000 & 0.000 \\
\hline Age & 165.765 & 132.161 & 1 & 135.478 & 132.161 & 58.563 & 50.858 & $<0.001$ & $<0.001$ \\
\hline Gender & 184.008 & 129.810 & 1 & 152.145 & 129.810 & 69.532 & 61.545 & $<0.001$ & $<0.001$ \\
\hline Age $\mathrm{x}$ gender & 23.667 & 21.667 & 1 & 23.667 & 21.667 & 13.666 & 11.213 & $<0.01$ & $<0.01$ \\
\hline
\end{tabular}

TOV, total orbital volume; TOFV, total orbital fat volume; ANOVA, analysis of variance; d.f., degrees of freedom.
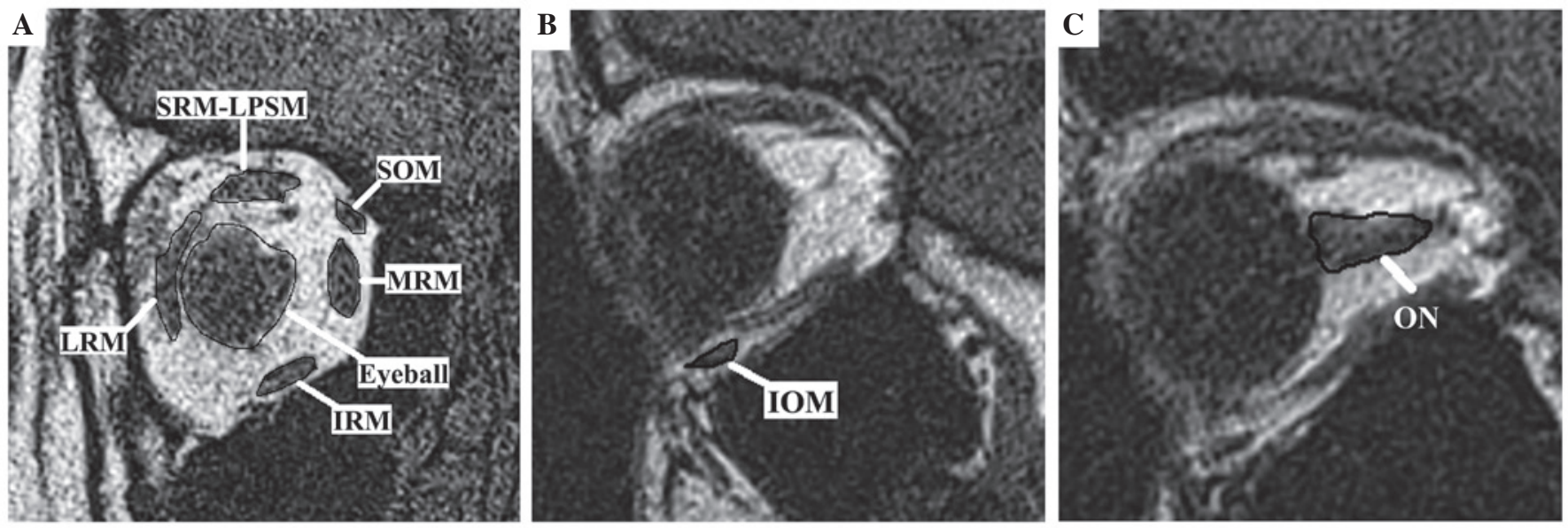

Figure 2. Structures used to calculate the total orbital volume in T1-weighted (A) coronal and (B and C) sagittal images. IOM, inferior oblique muscle; IRM, inferior rectus muscle; LRM, lateral rectus muscle; MRM, medial rectus muscle; ON, optic nerve; SOM, superior oblique muscle; SRM-LPSM, superior rectus-levator palpebrae superioris muscle complex.

an interactive effect between age and gender $(\mathrm{P}<0.01)$; as age increased, the TOV of men increased more rapidly than that of women.

TOFV. The mean TOFV was $11.48 \pm 1.81 \mathrm{~cm}^{3}$ for men, and $12.15 \pm 1.66 \mathrm{~cm}^{3}$ for women, the overall mean for the study population being $11.81 \pm 1.88 \mathrm{~cm}^{3}$. The mean TOFV of women was significantly greater than that of men $(\mathrm{P}<0.001)$. The mean TOFV of all subjects in group $\mathrm{V}$ was greater than that of the mean TOFV values of all other groups $(\mathrm{P}<0.001)$, which showed that TOFV also increased with age (Table II). There was no significant difference between the right and left orbital volumes for either gender. There was an interactive effect between age and gender $(\mathrm{P}<0.01)$; as age increased, 
Table IV. Results of multiple regression analysis for TOV, using body parameters (height and weight) as independent variables.

\begin{tabular}{|c|c|c|c|c|c|c|}
\hline \multirow[b]{2}{*}{ Age } & \multirow[b]{2}{*}{ Predictors } & \multicolumn{2}{|c|}{ Unstandardized coefficients } & \multirow{2}{*}{$\begin{array}{l}\text { Standardized } \\
\text { coefficient } \beta\end{array}$} & \multirow[b]{2}{*}{$\mathrm{t}$} & \multirow[b]{2}{*}{ P-value } \\
\hline & & $\mathrm{B}$ & SE & & & \\
\hline \multicolumn{7}{|l|}{ Group I } \\
\hline \multirow[t]{3}{*}{ Male } & Constant & 5.706 & 6.816 & & 0.637 & 0.529 \\
\hline & Height & 0.057 & 0.055 & 2.411 & 1.027 & $0.003^{\mathrm{a}}$ \\
\hline & Weight & 0.091 & 0.031 & 2.498 & 2.981 & $0.006^{\mathrm{a}}$ \\
\hline \multirow[t]{3}{*}{ Female } & Constant & 0.068 & 5.413 & & 0.009 & 0.993 \\
\hline & Height & 0.061 & 0.049 & 2.385 & 2.173 & $0.005^{\mathrm{a}}$ \\
\hline & Weight & 0.064 & 0.045 & 2.419 & 1.422 & $0.004^{\mathrm{a}}$ \\
\hline \multicolumn{7}{|l|}{ Group II } \\
\hline \multirow[t]{3}{*}{ Male } & Constant & 11.254 & 5.833 & & 0.699 & 0.502 \\
\hline & Height & 0.081 & 0.049 & 2.481 & 1.311 & $0.048^{\mathrm{a}}$ \\
\hline & Weight & 0.074 & 0.029 & 2.433 & 2.989 & $0.006^{\mathrm{a}}$ \\
\hline \multirow[t]{3}{*}{ Female } & Constant & 8.866 & 6.312 & & 0.003 & 0.859 \\
\hline & Height & 8.303 & 0.039 & 2.311 & 2.215 & $0.004^{\mathrm{a}}$ \\
\hline & Weight & 0.061 & 0.035 & 2.851 & 1.328 & $0.008^{\mathrm{a}}$ \\
\hline \multicolumn{7}{|l|}{ Group III } \\
\hline \multirow[t]{3}{*}{ Male } & Constant & 21.185 & 19.664 & & 2.809 & 0.009 \\
\hline & Height & 0.098 & 0.089 & 2.307 & 1.738 & $0.008^{\mathrm{a}}$ \\
\hline & Weight & 0.086 & 0.031 & 2.487 & 2.753 & $0.007^{\mathrm{a}}$ \\
\hline \multirow[t]{3}{*}{ Female } & Constant & 9.505 & 6.434 & & 2.099 & 0.420 \\
\hline & Height & 0.006 & 0.041 & 2.021 & 0.141 & $0.004^{\mathrm{a}}$ \\
\hline & Weight & 0.065 & 0.024 & 2.405 & 2.758 & $0.009^{\mathrm{a}}$ \\
\hline \multicolumn{7}{|l|}{ Group IV } \\
\hline \multirow[t]{3}{*}{ Male } & Constant & 26.214 & 22.545 & & 2.211 & 0.569 \\
\hline & Height & -0.434 & -0.387 & -0.255 & 1.782 & 0.299 \\
\hline & Weight & 0.124 & 0.198 & 0.359 & 1.958 & 0.485 \\
\hline \multirow[t]{3}{*}{ Female } & Constant & 6.426 & 8.102 & & 2.013 & 0.682 \\
\hline & Height & 0.312 & 0.299 & 0.019 & 0.155 & 0.799 \\
\hline & Weight & 0.063 & 0.021 & 2.898 & 2.598 & $0.009^{\mathrm{a}}$ \\
\hline \multicolumn{7}{|l|}{ Group V } \\
\hline \multirow[t]{3}{*}{ Male } & Constant & 28.216 & 23.663 & & 2.809 & 0.419 \\
\hline & Height & -0.155 & 0.098 & -0.207 & 1.738 & 0.313 \\
\hline & Weight & 0.148 & 0.131 & 0.487 & 2.753 & 0.411 \\
\hline \multirow[t]{3}{*}{ Female } & Constant & 9.505 & 6.434 & & 2.099 & 0.630 \\
\hline & Height & 0.214 & 0.141 & 0.021 & 0.141 & 0.711 \\
\hline & Weight & 0.065 & 0.024 & 2.316 & 2.758 & $0.009^{\mathrm{a}}$ \\
\hline
\end{tabular}

${ }^{\mathrm{a}} \mathrm{P}<0.01$. TOV, total orbital volume; $\mathrm{SE}$, standard error.

the TOFV of women increased more rapidly than that of men (Table III and Fig. 3).

Correlations. While both weight and height showed a positive correlation with TOV in male and female subjects in groups I-III, only weight showed a positive correlation with TOV in the female subjects in groups IV and V. In all groups, TOFV showed a positive correlation with weight, but no significant correlation with height was observed. The effects of the body parameters (height and weight) on the changes in TOV and TOFV with respect to age and gender are shown in Tables IV and V.

Statistical analysis of the results confirms that as age increases TOV and TOFV also increase; however, the correlation of these volumetric parameters was not found to be statistically significant (Pearson's bivariate correlation coefficient, 0.58, $\mathrm{P}=0.02$ ). 
Table V. Results of multiple regression analysis for TOFV, using body parameters (height and weight) as independent variables.

\begin{tabular}{|c|c|c|c|c|c|c|}
\hline \multirow[b]{2}{*}{ Age } & \multirow[b]{2}{*}{ Predictors } & \multicolumn{2}{|c|}{ Unstandardized coefficients } & \multirow{2}{*}{$\begin{array}{l}\text { Standardized } \\
\text { coefficients } \beta\end{array}$} & \multirow[b]{2}{*}{$\mathrm{t}$} & \multirow[b]{2}{*}{ P-value } \\
\hline & & $\mathrm{B}$ & SE & & & \\
\hline \multicolumn{7}{|l|}{ Group I } \\
\hline \multirow[t]{3}{*}{ Male } & Constant & 11.214 & 9.213 & & 0.582 & 0.503 \\
\hline & Height & 0.051 & 0.056 & 2.864 & 1.386 & 0.697 \\
\hline & Weight & 0.082 & 0.038 & 2.194 & 2.107 & $0.006^{\mathrm{a}}$ \\
\hline \multirow[t]{3}{*}{ Female } & Constant & 0.044 & 4.832 & & 0.089 & 0.993 \\
\hline & Height & 0.037 & 0.041 & 2.657 & 2.547 & 0.857 \\
\hline & Weight & 0.048 & 0.039 & 2.189 & 1.875 & $0.004^{\mathrm{a}}$ \\
\hline \multicolumn{7}{|l|}{ Group II } \\
\hline \multirow[t]{3}{*}{ Male } & Constant & 18.315 & 16.212 & & 2.341 & 0.614 \\
\hline & Height & 0.068 & 0.086 & 1.954 & 1.378 & 0.313 \\
\hline & Weight & 0.041 & 0.034 & 2.965 & 2.656 & $0.006^{\mathrm{a}}$ \\
\hline \multirow[t]{3}{*}{ Female } & Constant & 10.265 & 8.205 & & 3.012 & 0.391 \\
\hline & Height & 0.006 & 0.061 & 2.861 & 0.398 & 0.424 \\
\hline & Weight & 0.090 & 0.021 & 2.613 & 2.265 & $0.008^{\mathrm{a}}$ \\
\hline \multicolumn{7}{|l|}{ Group III } \\
\hline \multirow[t]{3}{*}{ Male } & Constant & 21.315 & 18.542 & & 2.341 & 0.216 \\
\hline & Height & 0.072 & 0.078 & 1.832 & 1.378 & 0.548 \\
\hline & Weight & 0.039 & 0.038 & 2.818 & 2.656 & $0.007^{\mathrm{a}}$ \\
\hline \multirow[t]{3}{*}{ Female } & Constant & 12.365 & 9.268 & & 3.012 & 0.256 \\
\hline & Height & 0.058 & 0.069 & 2.317 & 0.398 & 0.854 \\
\hline & Weight & 0.099 & 0.019 & 2.326 & 2.265 & $0.009^{\mathrm{a}}$ \\
\hline \multicolumn{7}{|l|}{ Group IV } \\
\hline \multirow[t]{3}{*}{ Male } & Constant & 22.498 & 20.128 & & 2.785 & 0.212 \\
\hline & Height & 0.098 & 0.066 & 1.919 & 1.585 & 0.366 \\
\hline & Weight & 0.049 & 0.031 & 2.625 & 2.965 & $0.006^{\mathrm{a}}$ \\
\hline \multirow[t]{3}{*}{ Female } & Constant & 13.294 & 10.025 & & 3.444 & 0.125 \\
\hline & Height & 0.098 & 0.081 & 2.825 & 0.325 & 0.568 \\
\hline & Weight & 0.065 & 0.023 & 2.448 & 2.265 & $0.004^{\mathrm{a}}$ \\
\hline \multicolumn{7}{|l|}{ Group V } \\
\hline \multirow[t]{3}{*}{ Male } & Constant & 23.214 & 22.838 & & 2.425 & 0.554 \\
\hline & Height & 0.001 & 0.098 & 0.189 & 1.284 & 0.197 \\
\hline & Weight & 0.148 & 0.0184 & 0.397 & 2.697 & $0.005^{\mathrm{a}}$ \\
\hline \multirow[t]{3}{*}{ Female } & Constant & 17.212 & 11.232 & & 2.536 & 0.265 \\
\hline & Height & 0.291 & 0.182 & 0.029 & 0.261 & 0.265 \\
\hline & Weight & 0.086 & 0.018 & 1.093 & 2.256 & $0.009^{\mathrm{a}}$ \\
\hline
\end{tabular}

${ }^{a} \mathrm{P}<0.01$. TOFV, total orbital fat volume; SE, standard error.

\section{Discussion}

This study evaluated orbital volumetric parameters and the correlation of these measurements with age, gender and body parameters (height and weight) in a group of 1,453 subjects with exclusion of any previous orbital disease history, using MRI, and is one of the largest series in the literature. The high number of patients may be attributable to the high number of patients with multiple sclerosis in this region of the country, who frequently present with visual symptoms and undergo MRI for them. The orbit is a limited anatomical structure filled with eyeball, non-compressible fluid and orbital cavity soft tissues. Atchison et al and Chau et al $(3,4)$ reported that MRI provided more accurate results than $\mathrm{CT}$ in orbital and eyeball volume measurements and that the average orbital volume was $20.9 \mathrm{~cm}^{3}$ in an Asian population, and Forbes et al (12) 


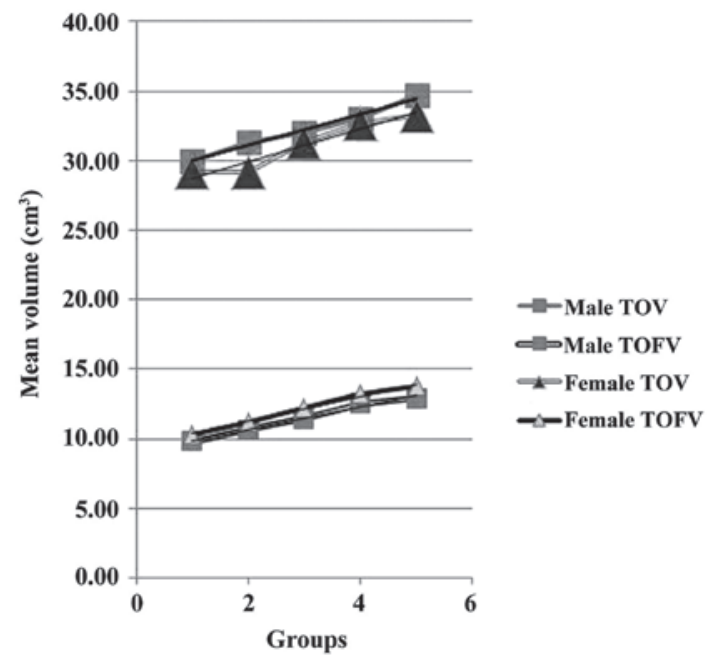

Figure 3. Interactive effect between age and gender on total orbital volume (TOV) and total orbital fat volume (TOFV).

identified an upper limit of $30.1 \mathrm{~cm}^{3}$ for normal bony orbit in Western individuals. These values are smaller than those in the present study since they were obtained only from the bony orbit, and did not include anterior soft tissues of the orbit. A study carried out in the United States using CT, which also included all of the soft tissues around the eye showed similar volumetric values as the present study, which suggests that the size of the orbits in the Anatolian population resemble those of Western individuals, in contrast to those of the Far Eastern world (13).

In the literature, the average orbital volumetric changes with respect to gender are controversial. Certain studies found larger orbital volumes in men than women $(3,14)$, while another (12) found no statistically significant difference. In the present study, it was observed that the average TOV was larger in men than in women. This result may be attributed to the fact that the axial skeleton is greater in size in men than in women, which would affect the bony orbit as well. It has been reported that orbital size correlates well with the bone size of the whole body skeleton as a result of the growth pattern, and also with skull length $(3,5)$, which may explain the difference between genders. There was also an interactive effect between age and gender: As age increased, the TOV of men increased more rapidly than that of women. Since the bony elements decrease with age in the whole body (15), the finding that decrements in orbital angles and the volume of the bony orbit also occur with age, in a similar manner to those in the axial skeleton $(16,17)$ is not surprising. However, considering the results of the present study, the total volume loss of the orbital structures appears to be less than that of the bony orbital volume, which may be due to replacement of the lost volume with adipose tissue.

Regarding the changes in TOV with respect to the body parameters, positive correlations were observed with both weight and height in male and female subjects in group I-II. As orbital volume has an association with bony elements, Shaw et al (17) pointed out that orbital bony changes are similar to those of the axial skeleton. Kirchengast et al (18) suggested that a lower weight status and a low amount of lean body mass may be associated with increased bone loss, and Gracia-Marco et al (19) showed that adolescents with a low level of fitness had a lower bone mineral content. Therefore, it can be concluded that the orbital volume has a positive correlation with weight as well as height. However, in the present study, only weight showed a positive correlation with TOV in female subjects older than 50 years of age. Kirchengast et al (18) suggested that the absolute fat mass had a significant impact on bone mineral density in females, due to the diminished conversion rates from androgens to estrogens in a low amount of adipose tissue. Since high amounts of fat tissue are particularly present in elderly women, this can explain our results. However, further studies based on physiological and biological analysis are required to clarify this issue.

TOFV is an important indicator of eye movements, eyelid configuration and function. It is known that loss of TOFV due to any cause causes eyelid retraction or proptosis that requires reconstruction to restore functional anatomy and aesthetic facial appearance, and in several studies $(20,21)$ orbital fat volume augmentation is discussed. In the present study, the average TOFV of women was significantly greater than that of men. Additionally, the average TOFV increased as age increased. This is in contrast with the speculation of Ahmadi et al (22) that the orbital adipocytes undergo atrophy with advancing age. The significant correlation of age with TOFV may be attributable to a relative reduction in muscular bulk and volume of the globe itself with increasing age $(23,24)$. In addition, Darcy et al (25) observed an increase in total orbital fat and periocular soft tissue with aging, which they claimed was due to fat expansion, which is consistent with the results of the present study, and which may be the rationale for fat excision from the eyelids in plastic and aesthetic surgery. Although the present study revealed an increase in TOFV and TOV with respect to age, there was no statistically significant correlation between the changes in TOFV and TOV, which should be further investigated. There was a positive interactive effect with age and gender regarding TOFV, showing that as age increased the TOFV of women increased more rapidly than that of men. In contrast to some studies $(26,27)$, TOFV showed a positive correlation with weight in the present study. It is suggested that with increment of weight, as the distribution of fatty tissues varies in the body, this also affects the TOFV values. When age is considered, following hormonal changes in the postmenopausal period, the abnormal increase of fatty tissues in women may explain the results of the present study. Further studies based on body mass index are required to support this hypothesis. Another limitation of this study is that it was carried out in a certain limited population, despite its large size, and, therefore, may not be valid in various parts of the world, such as eastern Asia.

To conclude, the study findings provide basic information about orbital volume changes due to gender and body parameters and may aid in clinical practice, such as when studying the mechanisms of exophthalmos in Graves' orbitopathy, planning orbital decompression or orbital reconstruction following fractures, or the size of orbital implants following enucleation, blepharoplasty and other esthetic procedures involving eyelids and retroorbital fatty tissue. In addition, knowing the normal size and proportions of the contents of the orbit may help diagnosing unilateral ophthalmopathy. 


\section{Acknowledgements}

Main topics of this study have been accepted for oral presentation, and were presented at ECR 2014, Vienna, Austria with presentation No. B-0171.

\section{References}

1. Quatrehomme G and Gérard S: Classical noncomputer-assisted craniofacial reconstruction. In: Computer-Graphic Facial Reconstruction. Clement JG and Marks MK (eds). Elsevier, Burlington, MA, pp15-32, 2005.

2. Bentley RP, Sgouros S, Natarajan K, et al: Normal changes in orbital volume during childhood. J Neurosurg 96: 742-746, 2002.

3. Atchison DA, Jones CE, Schmid KL, et al: Eye shape in emmetropia and myopia. Invest Ophthalmol Vis Sci 45: 3380-3386, 2004.

4. Chau A, Fung K and Yap M: Evaluation of the accuracy of volume determination on the orbit and eyeball using MRI. Radiography 11: 35-39, 2005.

5. Ranly DM: Craniofacial growth. Dent Clin North Am 44: 457-470, 2000

6. Kahn DM and Shaw RB Jr: Aging of the bony orbit: A three-dimensional computed tomographic study. Aesthet Surg J 28: 258-264, 2008

7. Kim SP, Lee BY, Lee SJ, et al: A study on orbital volume of Korean people in their 20s or 40s. Ophthalmic Res 47: 98-102, 2012.

8. Detorakis ET, Drakonaki E, Papadaki E, Pallikaris IG and Tsilimbaris MK: Effective orbital volume and eyeball position: An MRI study. Orbit 29: 244-249, 2010.

9. Darcy SJ, Hakimi M, Miller TA, Goldberg RA, Evans GR, Demer JL and Rudkin GH: Magnetic resonance imaging characterization of orbital soft-tissue volume dynamics with age. Plast Reconstr Surg 124: 1362-1364, 2009.

10. Detorakis ET, Engstrom RE, Straatsma BR and Demer JL: Functional anatomy of the anophthalmic socket: Insights from magnetic resonance imaging. Invest Ophthalmol Vis Sci 44 4307-4313, 2003.

11. Detorakis ET, Drakonaki EE, Papadaki E, Tsilimbaris MK and Pallikaris IG: Evaluation of globe position within the orbit: Clinical and imaging correlations. Br J Ophthalmol 94: 135-136, 2010.

12. Forbes G, Gehring DG, Gorman CA, Brennan MD and Jackson IT: Volume measurements of normal orbital structures by computed tomographic analysis. AJR Am J Roentgenol 145 : $149-154,1985$.
13. Özkan AY, Karmonik C, Chaudhry IA, Arat A, Totan S and Yüksel E: Measurement of eyelid and orbital fat volume in different age groups by computed tomography. Turkiye Klinikleri J Med Sci 30: 995-1001, 2010.

14. Furuta M: Measurement of orbital volume by computed tomography: Especially on the growth of the orbit. Jpn J Ophthalmol 45: 600-606, 2001.

15. Shaw RB Jr and Kahn DM: Aging of the midface bony elements: A three-dimensional computed tomographic study. Plast Reconstr Surg 119: 675-683, 2007.

16. Richard MJ, Morris C, Deen BF, Gray L and Woodward JA: Analysis of the anatomic changes of the aging facial skeleton using computer-assisted tomography. Ophthal Plast Reconstr Surg 25: 382-386, 2009.

17. Shaw RB Jr, Katzel EB, Koltz PF, Kahn DM, Puzas EJ and Langstein HN: Facial bone density: Effects of aging and impact on facial rejuvenation. Aesthet Surg J 32: 937-942, 2012.

18. Kirchengast S, Peterson B, Hauser G and Knogler W. Body composition characteristics are associated with the bone density of the proximal femur end in middle- and old-aged women and men. Maturitas 39:133-145, 2001.

19. Gracia-Marco L, Vicente-Rodríguez G, Casajús JA, Molnar D, Castillo MJ and Moreno LA: Effect of fitness and physical activity on bone mass in adolescents: The HELENA Study. Eur J Appl Physiol 111: 2671-2680, 2011.

20. Lee JY, Lee KH, Shin HM, Chung KH, Kim GI and Lew H: Orbital volume augmentation after injection of human orbital adipose-derived stem cells in rabbits. Invest Ophthalmol Vis Sci 54: 2410-2416, 2013

21. Park J, Cho HK and Moon JI: Changes to upper eyelid orbital fat from use of topical bimatoprost, travoprost, and latanoprost. Jpn J Ophthalmol 55: 22-27, 2011.

22. Ahmadi H, Shams PN, Davies NP, Joshi N and Kelly MH: Age-related changes in the normal sagittal relationship between globe and orbit. J Plast Reconstr Aesthet Surg 60: 246-250, 2007.

23. Hahn FJ and Chu WK: Ocular volume measured by CT scans. Neuroradiology 26: 419-420, 1984.

24. Smith P: On the size of the cornea in relation to age, sex, refraction and primary glaucoma. Trans Ophthalmol Soc UK 10: 68-78, $18 \mathrm{p} 0$.

25. Darcy SJ, Miller TA, Goldberg RA, Villablanca JP, Demer JL and Rudkin GH: Magnetic resonance imaging characterization of orbital changes with age and associated contributions to lower eyelid prominence. Plast Reconstr Surg 122: 921-931, 2008.

26. Castanares S: Blepharoplasty for herniated intraorbital fat; anatomical basis for a new approach. Plast Reconstr Surg (1946) 8: 46-58, 1951.

27. Sires BS, Lemke BN, Dortzbach RK and Gonnering RS: Characterization of human orbital fat and connective tissue. Ophthal Plast Reconstr Surg 14: 403-414, 1998. 